\title{
Valpovačka zbirka Rudolfa i Julije Normann-Ehrenfels
}

Najcer Sabljak, Jasminka

Source / Izvornik: Institucije povijesti umjetnosti : zbornik 4. kongresa hrvatskih povjesničara umjetnosti, 2019, 51 - 63

Conference paper / Rad u zborniku

Publication status / Verzija rada: Published version / Objavljena verzija rada (izdavačev PDF)

https://doi.org/10.31664/z4khpu.07

Permanent link / Trajna poveznica: https://urn.nsk.hr/urn:nbn:hr:254:569982

Rights / Prava: Attribution 4.0 International/Imenovanje 4.0 međunarodna

Download date / Datum preuzimanja: 2023-04-26

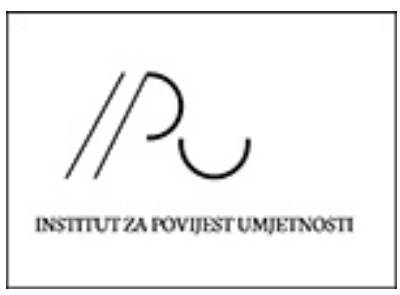

Repository / Repozitorij:

PODEST - Institute of Art History Repository

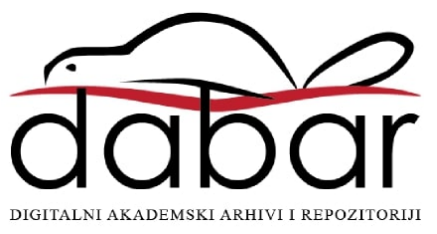




\section{Valpovačka zbirka Rudolfa i Julije Normann-Ehrenfels}

\section{Dosadašnje spoznaje o valpovačkoj zbirci}

Baština plemićkih obitelji u razdoblju od početka i8. do sredine 20. stoljeća predstavlja važan dio kulturnog identiteta istočne Hrvatske, a njihova je likovna baština do sada samo djelomično istražena, publicirana i prezentirana. Valpovačku zbirku stvarali su članovi barunske obitelji Hilleprand von Prandau i grofovske obitelji Normann-Ehrenfels, koji su upravljali valpovačkim posjedom u navedenom vremenu. Zbirka je dio bogatoga kulturnog nasljeđa najvažnijih vlastelinskih obitelji ovoga područja, među koje ubrajamo i obitelji Pejačević, Eltz te Odescalchi. ${ }^{1}$

Dosad je u suradnji s nizom stručnjaka iz zemlje i inozemstva temeljitije istražena likovna baština obitelji Pejačević te prezentirana javnosti u sklopu izložbe Muzeja likovnih umjetnosti iz Osijeka. ${ }^{2}$ Izložba je gostovala u nizu hrvatskih (Zagreb, Našice, Virovitica, Vukovar, Požega, Đakovo, Dubrovnik) i inozemnih (Ruma u Srbiji i Šopron u Mađarskoj) gradova, a na izložbi u Šopronu postojeća su istraživanja nadopunjena vrijednim doprinosima mađarskih autora. ${ }^{3}$ Vrijedna, premda malobrojna, baština talijanskih kneževa Odescalchi iz iločkog dvorca monografski je obrađena u knjizi Jasminke Najcer Sabljak. ${ }^{4}$ Dio građe grafičkih mapa i listova, kao važnih segmenata likovnih zbirki unutar plemićkih ostavština, predstavljen je na izložbi i u istoimenom katalogu Bakrorezi i bakropisi iz plemićkih zbirki Slavonije i Srijema u Muzeju likovnih umjetnosti u Osijeku. ${ }^{5}$

U daljnjim aktivnostima u sklopu projekta Skriveno blago europskog plemstva istražit će se i prezentirati likovna baština valpovačkih vlastelina te vukovarskih grofova Eltz, danas većinom raspršena $u$ fundusima hrvatskih i inozemnih muzeja, drugim baštinskim ustanovama i privatnim zbirkama. ${ }^{6}$

Likovna baština valpovačkih vlastelina fragmentarno je obrađena u sklopu monografija pojedinih slikara, kataloga izložbi i općih pregleda nacionalne povijesti umjetnosti, a djelomično prezentirana javnosti na stalnoj muzejskoj izložbi Ostavština

\section{Jasminka Najcer Sabljak}

Odsjek za vizualne i medijske kulture Akademija za umjetnost i kulturu u Osijeku Sveučilište Josipa Jurja Strossmayera u Osijeku jasminka.najcer@gmail.com

http://orcid.org/oooo-ooo2-II87-II22
I JASMINKA NAJCER SABLJAK, Likovna ostavština velikaških obitelji, u: Slavonija, Baranja i Srijem: vrela europske civilizacije (katalog izložbe, 27.4.-2. 8. 20og.), sv. 2., Galerija Klovićevi dvori, Zagreb, 2009., 464-469.

2 JASMINKA NAJCER SABLJAK, SILVIJA LUČEVNJAK, Likouna baština obitelji Pejačević (katalog izložbe, I9. 9. 20I3.-7. I. 20I4.), Galerija likovnih umjetnosti, Osijek, 20I3.

3 Pejacsevich Család Művészeti Öröksége (ur. Ferenc Veress), Matica hrvatska, Šopron, 2016.

4 JASMINKA NAJCER SABLJAK, Likovna baština kneževa Odescalchi od Lombardije i Rima do Iloka, Muzej likovnih umjetnosti, Društvo povjesničara umjetnosti Hrvatske, Muzej grada Iloka, Osijek, 20I5

5 JASMINKA NAJCER SABLJAK, Bakrorezi i bakropisi iz plemićkih zbirki Slavonije i Srijema (katalog izložbe, Io. I2. 20I5.-3I. I. 20I6.), Muzej likovnih umjetnosti, Osijek, 2OI5.

6 JASMINKA NAJCER SABLJAK (bilj. 4), I26. 
plemićke obitelji Prandau-Normann u Muzeju Valpovštine. ${ }^{7}$ Cjelovit uvid u količinu i vrstu sačuvanih djela iz valpovačke zbirke pruža doktorska disertacija Jasminke Najcer Sabljak Umjetničke zbirke vlastelinskih obitelji u Slavoniji i Srijemu, a njezino je značenje jasno istaknuto i na izložbi Slavonija, Baranja i Srijem: vrela europske civilizacije. ${ }^{8}$ Studiozniju analizu umjetničkih djela valpovačke zbirke i njezino prezentiranje donijela je izložba Valpovački vlastelini Prandau-Normann, a u ovom se tekstu pruža uvid u djelatnost Rudolfa i Julije Normann-Ehrenfels u kontekstu nastanka i razvoja zbirke, kao doprinos poznavanju povijesti kulturne baštine toga dijela Hrvatske. ${ }^{9}$

\section{Valpovački vlastelini i njihova zbirka}

Uspon i razvoj valpovačkog vlastelinstva u vremenu nakon oslobođenja od Osmanlija obilježile su gospodarskim, društvenim i kulturnim djelovanjem dvije ugledne plemićke obitelji stranoga porijekla. Veleposjed Valpovo baruni Hilleprand von Prandau dobili su r72I. godine, u vrijeme najutjecajnijeg člana obitelji na habsburškom dvoru Petra Antuna (Bozen, I676.-Beč, I767.). ${ }^{10}$ Njegovi su potomci ženidbenim vezama posjed donijeli u vlasništvo grofovske obitelj NormannEhrenfels, podrijetlom iz Njemačke. Upravo u vrijeme njihova upravljanja posjedom, potkraj I9. i početkom 20. stoljeća, on doseže najveći gospodarski i društveni uspon.

U vrijeme kada posjedom upravljaju Rudolf i Julija NormannEhrenfels u valpovačkom dvorcu nalazi se zbirka umjetnina koju su sakupljali njihovi prethodnici, tri generacije obitelji Hileprand von Prandau i jedna generacija obitelji NormannEhrenfels. Najstarija djela u zbirci podrijetlom su iz bečkih slikarskih atelijera, jer su baruni Prandau do kraja i8. stoljeća zapravo živjeli u Beču, a samo povremeno dolazili na valpovačko vlastelinstvo. Umjetnine su nabavljane kao import, a riječ je o prvorazrednom materijalu baroknoga slikarstva sredine i druge polovine I8. stoljeća, s naglaskom na radovima bečkih dvorskih slikara Ephraima Hochhausera i Johanna Michaela Rottmayra. Josip Ignjat, barun Prandau (Beč, I749.-Valpovo, I8ı6.) ženidbom se u trećem braku vezao uz lokalnu plemkinju, Anu Mariju, rođ. groficu Pejačević (Osijek, I776.-Pečuh, I863.). Nakon te ženidbe stalno se naselio u Valpovu i onamo prenio portrete obiteljske zbirke iz Beča. Bračni par Ignjat i Ana Marija početkom Ig. stoljeća naručili su i niz klasicističkih portreta kod bečkog slikara Antona Zitterera.

Tijekom I9. stoljeća narudžbe valpovačkih vlastelina i dalje su bile usmjerene prema stranim autorima. Ignjatov sin i nasljednik valpovačkog vlastelinstva bio je Gustav, barun Prandau (Valpovo, I807.-Donji Miholjac, I885.). On je sa suprugom Adelom, rođ. von Cseh (Vukovar, I802.-Valpovo, I869.) obogatio obiteljsku zbirku nizom portreta iz sredine ig. stoljeća. Umjetnine iz tog razdoblja ističu se kvalitetom, a time ukazuju na naglašenu sklonost naručitelja umjetnosti, koja je rezultirala vrijednim akvizicijama kod ponajboljih umjetnika tog
7 MIRJANA PAUŠAK, Ostavština plemićke obitelji Prandau-Normann (katalog izložbe), Muzej Valpovštine, Valpovo, 2009.

8 JASMINKA NAJCER SABLJAK, Umjetničke zbirke vlastelinskih obitelji u Slavoniji i Srijemu (neobjavljena doktorska disertacija), Filozofski fakultet, Zagreb, $2 \mathrm{OI} 2$.

9 Cjelovitiju obradu likovne zbirke valpovačkih vlastelina donijela je izložba Likouna baština PrandauNormann u Muzeju likovnih umjetnosti u Osijeku, vidi: dr. sc. JASMINKA NAJCER SABLJAK, SILVIJA LUČEVNJAK, Povijest likovne zbirke valpovačkih vlastelina, u: Valpovački vlastelini Prandau-Normann, katalog izložbe, Osijek, 20I8., II8- I29.

IO IVE MAŽURAN, Valpovo: sedam stoljeća znakovite prošlosti, Valpovo, 2004., I26. 
vremena. Među njima ističe se narudžba portreta triju kćeri Gustava i Adele (Štefanije, Marijane i Alvine) kod vrsnog bidermajerskog slikara Friedricha von Amerlinga. Nabavom reprezentativnoga slavonskog pejzaža od prvaka tzv. osječke crtačke škole, Huga Conrada von Hötzendorfa, barun Gustav pokazao je interes i za domaće slikare te dao poticaj formiranju i obrazovanju slikara na ovim prostorima.

Smrću baruna Gustava ugasila se valpovačka vlastelinska loza obitelji Prandau, no obiteljska se zbirka nije samo sačuvala nego i nastavila razvijati pod brigom njegove kćeri Marijane (Zagreb, I828.- Oberdöbling, I89I.), koja je u drugome braku bila udana za Konstantina, grofa Ehrenfelsa (Altenstein, I8I8. - Rothenthurn, I882.). U tom razdoblju nastala je galerija portreta bračnog para Marijane i Konstantina te njihove djece, naručena od uglednog udomaćenog slikara građanskih i plemićih portreta, Josipa Franje Mückea. ${ }^{11}$

Zahvaljujući kontinuitetu življenja u tom prostoru te brizi članova obitelji za kulturnu baštinu, u valpovačkom je dvorcu, sve do vremena Rudolfa i Julije Normann-Ehrenfels, ostao sačuvan velik broj vrijednih umjetnina, koji je taj bračni par dodatno obogatio.

\section{Rudolf i Julija na čelu valpovačkog vlastelinstva}

Rudolf, grof Normann-Ehrenfels (Valpovo, I857.- Valpovo, I942.) sin je Konstantina i Marijane Normann-Ehrenfels. Vjenčan je u Schrottenthurnu, I3. svibnja I89o. s Julijanom, rođ. Edle von Vest (Celje, I868. - Rothenturn, I959.), koja je tog dana slavila 22. rođendan. Mladenkina majka Augusta potječe iz poznate slavonske plemićke obitelji Adamović. Nažalost, nisu nam poznati detalji njihova odgoja i obrazovanja, no očigledno je da su u brak stupili s već formiranim afinitetom prema umjetnosti i obiteljskoj baštini. Nakon vjenčanja mladi je bračni par živio u kuriji u Bizovcu (južno od Valpova), no kako je Rudolfova majka umrla već iduće godine, valpovački su posjed preuzeli u trećinama braća Gustav, Rudolf i sestra Ana. Godine I892. diobenim je ugovorom bizovački dio posjeda preuzeo Rudolfov brat Gustav (Bizovac, I856.-Graz, I927.). S obzirom da je otkupio dio vlastelinstva od sestre Ane, Rudolf je počeo upravljati većim dijelom posjeda te se s obitelji preselio u valpovački dvorac (sl. I). Prema ugovoru pripali su mu majuri Valpovo, Gorica, Krtinjača i Jedinac te šumska okružja Valpovo, Koška i jedna polovica Poganovaca, odnosno veći zapadni dio valpovačkog imanja, kao i kuća baruna Hillepranda von Prandaua na središnjem trgu u osječkom Gornjem gradu, koja je obnovljena ı894. godine po nacrtima uglednog hrvatskog arhitekta Josipa pl. Vancaša, a vjerojatno je sadržavala i dio obiteljske umjetničke zbirke (sl. 2).

Dvorac obitelji Hilleprand von Prandau i Normann-Ehrenfels u Valpovu foto: Jasminka Najcer Sabljak
II BRANKA BALEN, Josip Franjo Mücke I82I.-I883 Galerija likovnih umjetnosti, Osijek, 2000.

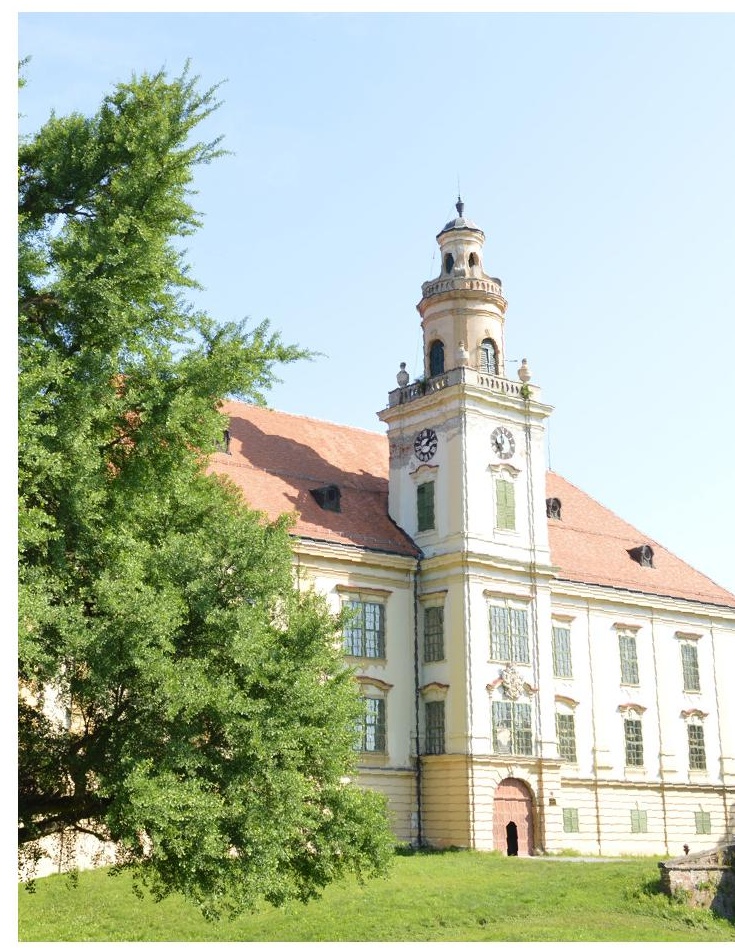




\section{Bračni par Normann-Ehrenfels i akvizicije za obiteljsku zbirku}

Rudolf i Julija Normann-Ehrenfels obiteljsku su zbirku obogatili nizom akvizicija, a pritom su posebnu pažnju posvetili otkupu djela od domaćih umjetnika. ${ }^{13} \mathrm{Na}$ prijelazu stoljeća hrvatska je likovna scena doživjela veliku promjenu, ponajviše potaknutu djelatnošću Društva hrvatskih umjetnika, udruženja osnovana I897. godine. Tada se skupina mladih umjetnika, okupljenih oko Vlahe Bukovca, odcijepila od Društva umjetnosti, koje je vodio Isidor Kršnjavi. Taj sukob starih i mladih, koji je započeo na izložbi Hrvatskoga salona I898. godine u Umjetničkom paviljonu kulminirao je idućih godina u nizu teoretskih osvrta i polemika te označio početak pokreta hrvatske moderne. Upravo u kontekstu nastanka novoga umjetničkog društva na hrvatskoj likovnoj sceni spomenuto je i ime grofa Rudolfa Normanna kao važne osobe i ljubitelja umjetnosti. ${ }^{14}$ No nakon sukoba u redovima umjetnika Društvo hrvatskih umjetnika gasi se tijekom rgo3. godine, a većina članova vraća se matičnom Društvu umjetnosti, koje mijenja ime u Hrvatsko društvo umjetnosti i počinje organizirati izložbe u gradovima izvan Zagreba, pa tako ıgo6. godine i u Osijeku. Katalog je zagrebačke izložbe sačuvan, no nije nam poznato da li je tiskan i za osječku izložbu, koja se održala uoči Božića iste godine. ${ }^{15} \mathrm{Na}$ toj su izložbi Rudolf i Julija kupili nekoliko djela hrvatskih umjetnika za svoju zbirku. ${ }^{16}$ Budući da se radilo o najskupljim umjetninama s te izložbe, svojom su kupnjom dali snažnu potporu mladoj nacionalnoj umjetničkoj sceni s Mencijem Clementom Crnčićem, Belom Čikoš-Sesijom i Celestinom Medovićem na čelu. ${ }^{17}$ Tako je u valpovačku zbirku ušlo nekoliko vrijednih slika predstavnika hrvatske moderne: Crnčićev Val, Čikoševi Trenkovi panduri i Medovićevo Groblje u Kuni. ${ }^{18}$

Nekoliko godina poslije Rudolf je naručio svoj portret kod domaćih slikara Jose Bužana (І9го.) i Vladimira Becića (ıgг2.; sl. 4). Tim je slikama prethodio Rudolfov dopojasni portret $u$ tada popularnoj tehnici oleografije, rađen prema litografskom predlošku, no Bužan i Becić portretirali su ga daleko reprezentativnije u smislu dimenzija i tehnike (ulje na platnu), kao i načinu prikaza lika. Grof je na objema slikama u gotovo punoj figuri, odjeven u ugarsku magnatsku odoru s mentenom i pripadnom opremom (lancem, čelenkom, dugmadi, sabljom), ukrašenom filigranskim radom, dijelom pozlaćenom i s umetnutim dragim kamenjem (koraljima, biserima i tirkizima). Iz valpovačke zbirke potječe i Bužanov portret Rudolfove kćeri Vere iz I9og. godine, možda nastao prilikom dogovora oko izrade Rudolfova portreta kod istog autora. Zanimljivo je spomenuti da Bužan tih godina izrađuje i portrete Normannova odvjetnika Dragutina Neumanna i supruge. ${ }^{19}$ Iste godine nastali su Verin portret u Beču i reprezentativni portret grofice Julije, rad popularnog austrijsko-mađarskog slikara aristokracije i društvene elite, Josepha Arpáda Koppaya, što ukazuje na dobro poznavanje ne samo domaće nego i šire, europske umjetničke scene onoga vremena. ${ }^{20}$
I3 O valpovačkoj zbirci i djelima hrvatske moderne umjetnosti vidi u: JASMINKA NAJCER SABLJAK, SILVIJA LUČEVNJAK, Moderna umjetnost u zbirkama slavonskog plemstva, u: Imago, Imaginatio, Imaginabile. Zbornik u čast Zvonka Makovića, Zagreb, 20I8., 247-265.

I4 OLGA MARUŠEVSKI, Društvo umjetnosti I868. - I879. I94I.: iz zapisaka Hrvatskog društva likovnih umjentika, Društvo povjesničara umjetnosti Hrvatske, Zagreb, 2004., I55-I56.

I5 Katalog izložbe Hrvatskog društva umjetnosti: izložba traje od I. rujna do I5. listopada I9o6., Zagreb, I9o6.

I6 RADOSLAV BAČIĆ, Likovna umjetnost u Osijeku, u: Jubilarni almanah Kluba hrvatskih knjižeunika i umjetnika u Osijeku, Osijek, I929., I26-I32.

I7 Hrvatski državni arhiv Zagreb (HR-HDA-I979), Izložba u Osijeku Igo6. - I9o7. Hrvatsko društvo likovnih umjetnika I879.- - 992., kutija I2.

I8 Bačić navodi da je kupljen i jedan rad slikara Tišova, no on zasad nije identificiran u valpovačkoj zbirci. RADOSLAV BAČIĆ (bilj. I6), ı28.

I9 Portreti su u fundusu Muzeja Slavonije.

20 Portreti su u fundusu Muzeja likovnih umjetnosti u Osijeku.

\section{Slika 4}

Vladimir Becić, Portret Rudolfa grofa Normanna-Ehrenfelsa Muzej likovnih umjetnosti, Osijek, MLU, S-7I9, Fototeka MLU

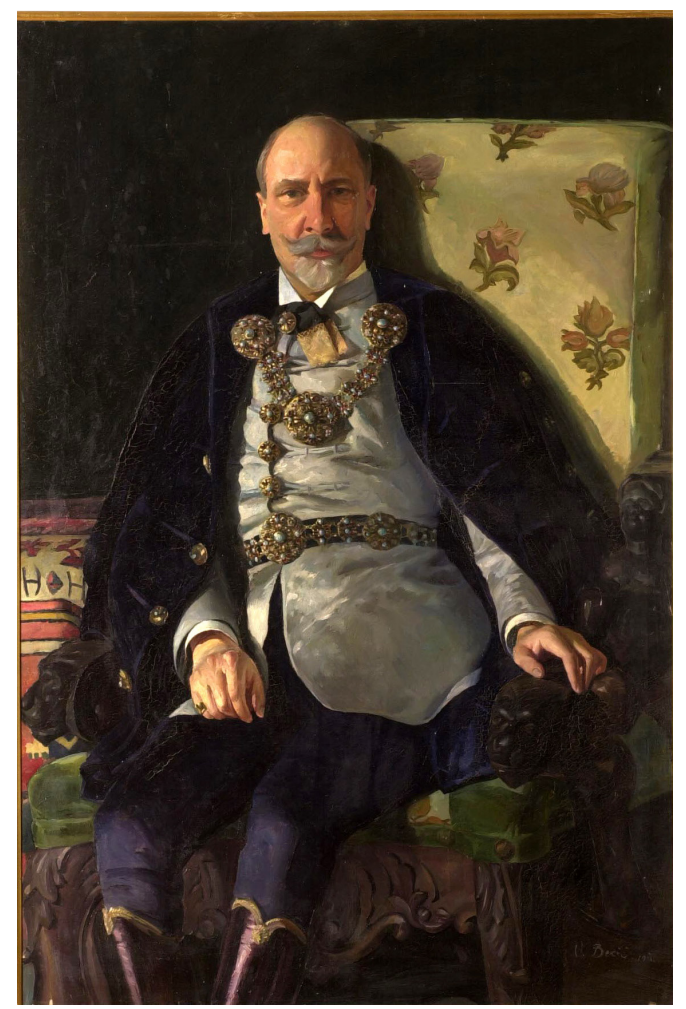



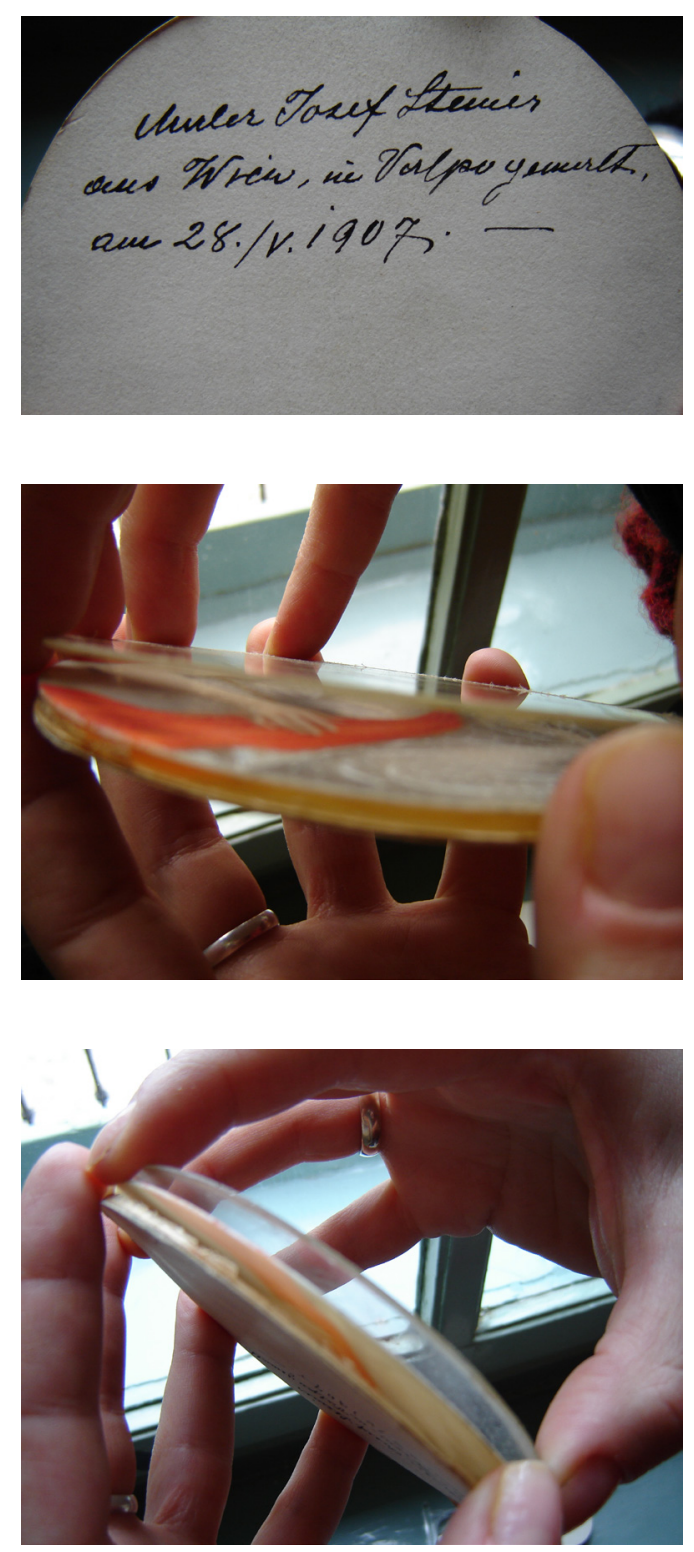
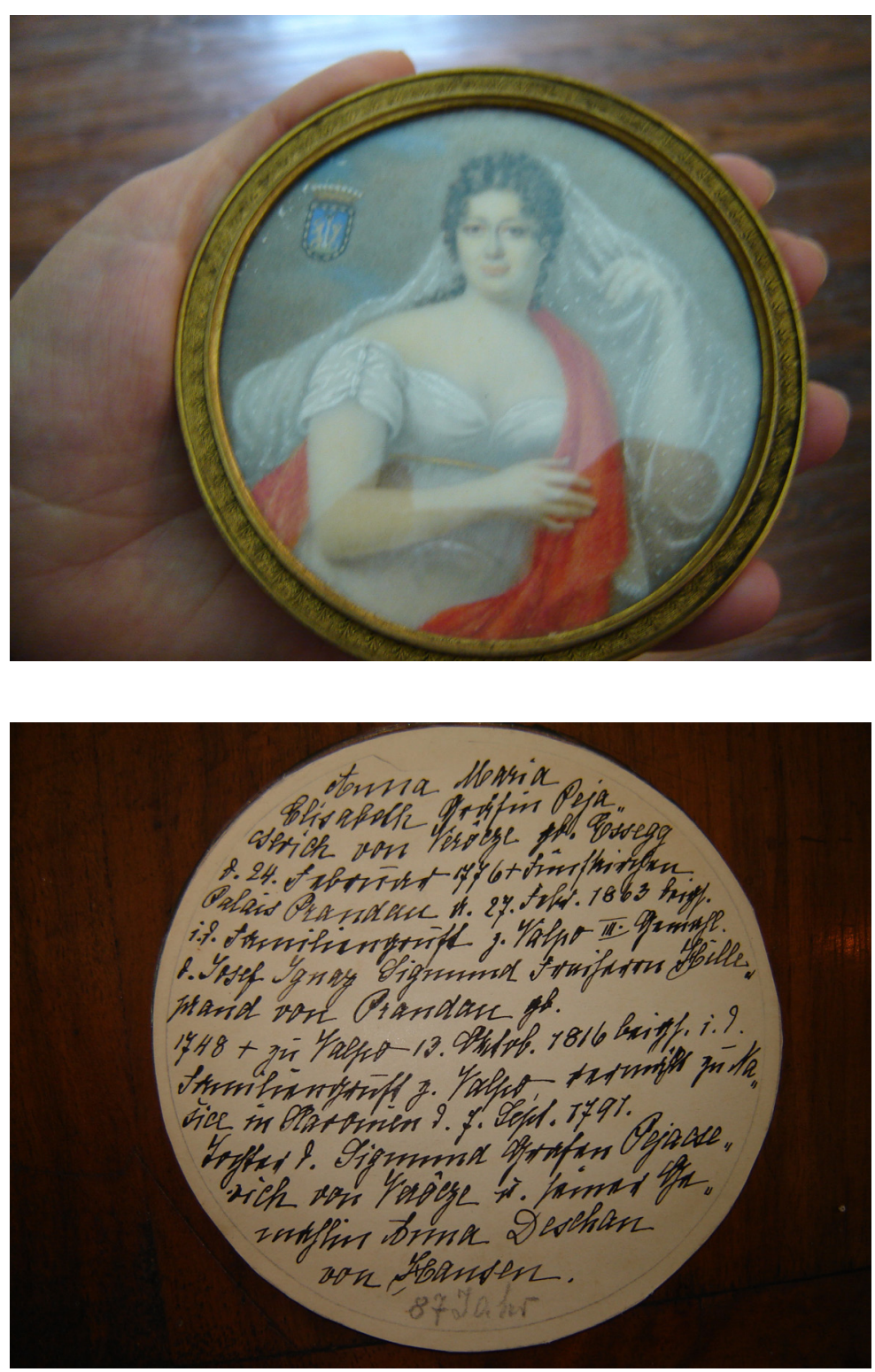

Slika 5

Josef Steiner, Portret Ane Marije Hilleprand von Prandau, rođ. Pejačević Igo3.

poleđina i unutrašnjost minijature sa signaturom, datacijom i mjestom nastanka, Valpovo, Muzej Valpovštine, MV-I504, foto: J. Najcer Sabljak 
Tih se godina na osječkoj umjetničkoj sceni pojavljuje slavonski slikar Dragan Melkus (I86o.-I9I7.), od kojeg je Rudolf kupio sliku Slavonska idila, izloženu na Prvoj umjetničkoj izložbi Kluba hrvatskih književnika, održanoj u Osijeku potkraj ıgı. i početkom rgor. godine. ${ }^{21}$

Osim kupnje umjetnina na izložbama Rudolf i supruga naručili su i izradu nadopune galerije predaka prema postojećim obiteljskim slikama u valpovačkom dvorcu, no u obliku minijatura. Pri toj su važnoj akviziciji angažirali austrijskog slikara Josefa Steinera, koji je dobio zadatak izvedbe dvadesetak portreta. U zbirci su već postojale portretne minijature iz Ig. stoljeća, a poticaj za izradu nove serije takvih slika možda je bila nabava minijature (akvarela na bjelokosti) jednoga Rudolfova pretka, Karla Ludwiga Normanna-Ehrenfelsa (ı8o8.- I856.), koja je naslikana ı9o6. u Stuttgartu. ${ }^{22}$ Steiner je od I9o6. do rgo8. godine u nekoliko navrata radio kopije postojećih portreta iz valpovačke zbirke u tehnici akvarela na bjelokosti i nešto u tehnici ulja na drvetu. Nastale su umjetnine nadopunile postojeće slike u obiteljskim rezidencijama u Valpovu, Osijeku i Rothenthurnu (sl. 5).

Osim što su bili izvedeni portreti predaka i rođaka obitelji Normann-Ehrenfelsa i Hilleprand von Prandau, Steiner je izradio i portrete vladara (Karl vi. Habsburški) te kneza izbornika (Friedrich von Württemberg), kao osoba zaslužnih za uspon obitelji. Na dvjema minijaturama portretiran je Rudolf Normann-Ehrenfelsa, a na jednoj je vjerojatno lik Rudolfove i Julijine kćeri Marije Ane ili Terezije. Osim navedenih minijatura, Steiner je oko ıgıo. u ulju na platnu naslikao i Julijin dopojasni portret u svečanoj haljini s dijademom na glavi (sl. 6), a dimenzijama ga je uskladio s već postojećim Rudolfovim dopojasnim portretom s početka 20. stoljeća u tehnici litografije, odnosno oleografije.

Nakon dulje vremena Steiner je izveo još nekoliko minijatura za valpovačku zbirku. Godine IgI8. u tehnici ulja na drvetu izveo je portret Julijine majke Auguste, a I920. u kombiniranoj tehnici (olovka, akvarel, gvaš na papiru) i portrete Julijine prabake i pradjeda iz grofovske obitelji Forgách. ${ }^{23} \mathrm{Uz}$ portrete, Rudolf i Julija Normann-Ehrenfels nabavili su i zanimljivo djelo Josefa Steinera potpuno drukčije tematike. Riječ je o slici (ulje na limu) s prizorom svetoga Huberta (zaštitnika lovaca) iz I9ı. godine. ${ }^{24} \mathrm{~S}$ obzirom na tematiku ostalih Steinerovih slika, očigledno je da su narudžbe morale dolaziti ponajviše od Julije Normann-Ehrenfelsa, jer je upravo njezinim precima u nizu minijatura posvećena posebna pozornost. Osim tih akvizicija, u valpovačkoj se zbirci nalazi još nekoliko slika koje su vjerojatno nabavili Rudolf i Julija, no manje likovne vrijednosti.

\section{Rudolf i Julija kao čuvari valpovačke i podgoračke zbirke}

Uz velik broj novih umjetnina koje su Rudolf i Julija kupili za valpovačku zbirku, posebno mjesto u njihovoj skrbi za umjetnine zauzima odnos prema dijelu umjetnina u valpovačkom dvorcu koja čine posebnu cjelinu, odnosno izdvojenu likovnu zbirku s obzirom na način nastanka i dolaska u Valpovo. Naime,
2I Prva umjetnička izložba priređena po „Klubu hrvatskih književnika" u Osijeku, u velikoj dvorani županijske zgrade (katalog izložbe, 26. I2. I9Io.-I5. I. I9II.), Osijek.

22 ANDREJA ŠIMIČIĆ, Ljupki čuvari uspomena, Portretna minijatura iz zbirke slika i okvira Muzeja Slavonije, katalog izložbe, Osijek, 20I4., I7-22.

23 Steinerove su minijature $u$ fundusu Muzeja Valpovštine, a veliki Julijin portret u fundusu Muzeja likovne umjetnosti u Osijeku.

24 Slika je u fundusu Muzeja Slavonije. 


\section{Slika 6}

Josef Steiner, Portret Julije Normann-Ehrenfels, rođ. Edle von Vest

Muzej likovnih umjetnosti, Osijek, MLU-S-729,

Fototeka MLU

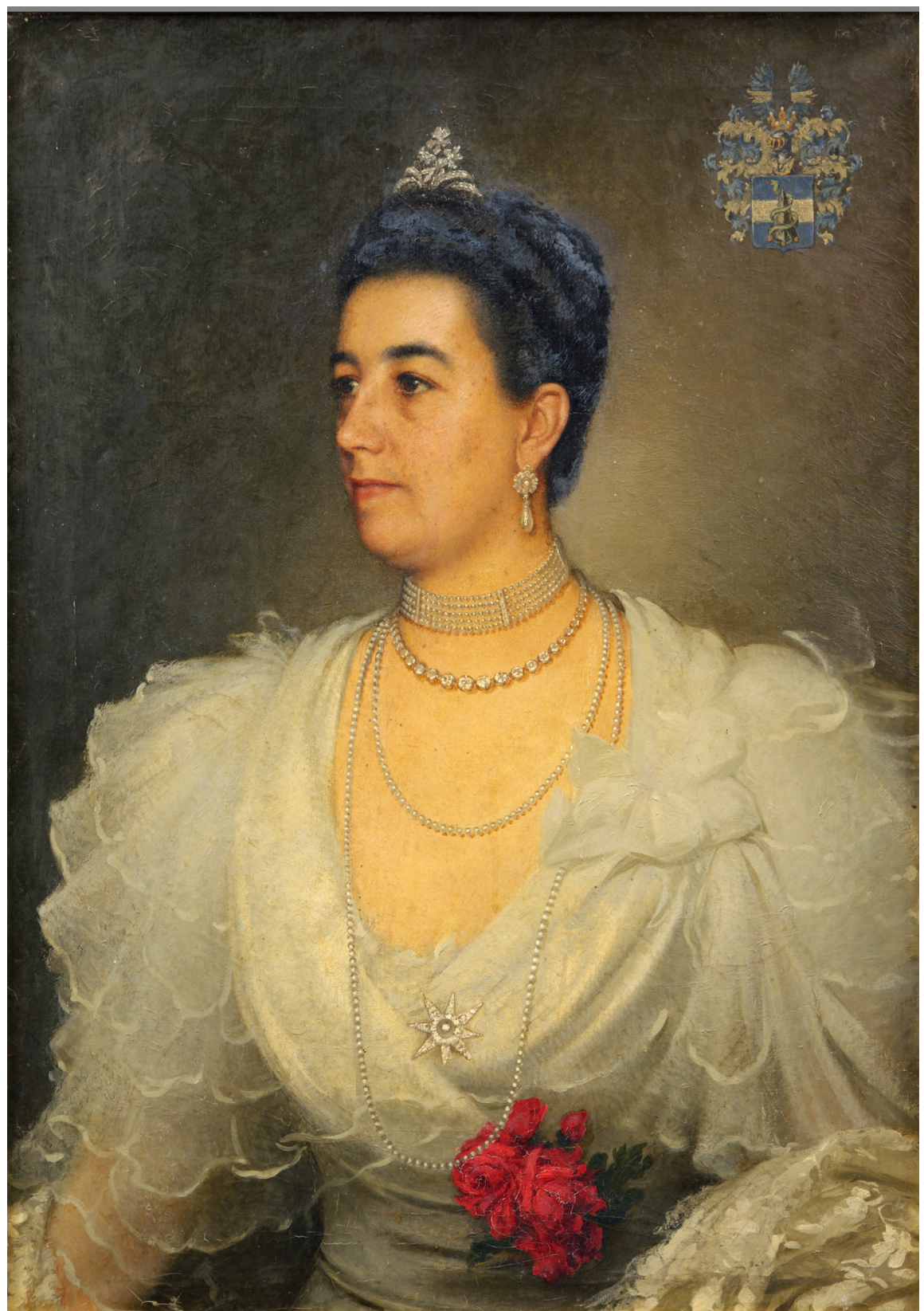


unutar obiteljske kolekcije Rudolf i Julija godinama su se brinuli i o djelima podgoračke zbirke, koja je u njihov dvorac došla zahvaljujući kupnji podgoračkoga vlastelinstva. Do te je akvizicije vjerojatno došlo i zahvaljujući činjenici da su imali ne samo financijske mogućnosti za tu kupnju nego i sklonost za umjetnost, što je mogao prepoznati Pavao, grof Pejačević (Retfala, I8I3.--Podgorač, ı907.), vlastelin Podgorača. On je svoj posjed, zajedno s inventarom i bogatom likovnom zbirkom podgoračkog dvorca, prodao prije smrti grofu Rudolfu, s pravom doživotnog uživanja. Grof Pejačević bio je rodbinski povezan s Rudolfom preko supruge Alvine, rođ. Hilleprand von Prandau (Vukovar, I830.-Ausseebach, I882.), sestre Rudolfove majke Marijane. Bračni par Pejačević sredinom ig. stoljeća formirao je impozantnu zbirku umjetnina u svom dvorcu u Podgoraču nedaleko Našica. Zbirka je prema sačuvanom popisu inventara s početka 20. stoljeća brojala oko devedeset slika, grafika i skulptura. U njoj su se nalazila djela austrijskih i ugarskih slikara, ponajviše predstavnika bidermajera, romantizma i realizma (Karla Rahla, Móra Thana, Alajosa Györgyija Giergla, Josefa Hoffmanna, Antala Ligetija, Józsefa Engela). Kvalitetom se u zbirci ističu obiteljski portreti bečkog slikara i profesora Karla Rahla, koji je u zbirci zastupljen i krajolicima, žanr-scenama te s nekoliko kopija nastalih prema poznatim renesansnim slikama Tiziana i Bordonea. ${ }^{25}$

Rudolf je nakon smrti grofa Pejačevića, a prije Prvoga svjetskog rata, umjetnine prenio iz Podgorača u Valpovo. Tako ne samo da je njegov dvorac bio obogaćen vrijednim likovnim materijalom nego je i podgoračka zbirka bila spašena neizvjesne sudbine i vjerojatnoga potpunog nestanka. Naime, tijekom Drugoga svjetskog rata podgorački je dvorac bio teško oštećen u ratnim zbivanjima i poslije srušen. Djela podgoračke zbirke više od četiri desetljeća bila su dio inventara valpovačkog dvorca, a nakon Drugoga svjetskog rata pratila su njihovu sudbinu i bila prenesena u osječki muzej.

U vrijeme gospodarskoga prosperiteta obitelji Rudolf i Julija povećali su brigu za naslijeđenu kolekciju umjetnina ne samo narudžbom i nabavom novih djela nego i izradom kopija slika te restauracijom starih slika, što je podrazumijevalo aplikaciju obiteljskih grbova na postojeće portrete. Doslikavanje obiteljskih grbova bio je posebno osjetljiv zadatak, za koji su se Rudolf i Julija Normann dobro pripremili, kako bi posao bio izveden u skladu s pravilima heraldičke struke. U Muzeju Valpovštine ostala je sačuvana mapa sa skicama grbova obitelji valpovačkih vlastelina i s njima povezanih obitelji (Lattermann, Pejačević, Vest...). To su bili predlošci za doslikane grbove, aplicirane na gotovo sve obiteljske portrete u valpovačkoj zbirci. Skice su potpisane s Krahl, a na pozadini crteža nalazi se pečat carskog i kraljevskog heraldičara Ernsta Krahla (sl. 7) ${ }^{26}$ Uglednog austrijskog heraldičara Rudolf i Julija angažirali su za nacrte grbovlja na obiteljskim portretima, a njegov je predložak poslužio slikarima koji su u to vrijeme bili angažirani na zbirci. Sigurno je da su se tim grbovima služili npr. Koppay i Steiner na novonastalim slikama, no zasad nije poznato tko ih je izveo na starim portretima.
$25 \mathrm{O}$ podgoračkoj zbirci vidi u: JASMINKA NAJCER SABLJAK, Skriveno blago podgoračkog dvorca, u: Osječki zbornik, 30 (20II.), I59-I79.

26 Ernst Krahl (I858.-ı926. ) bio je njemačko-austrijski heraldičar, crtač ekslibrisa, završio je prvobitno dresdensku potom bečku Akademiju. Bio je član austrijskog društva Ex libris. Njegovi ekslibrisi nalaze se u brojnim kolekcijama. HEINRICH FUCHS, Die österreichischen Maler des I9. Jahrhunderts, Beč, I973.,I32.
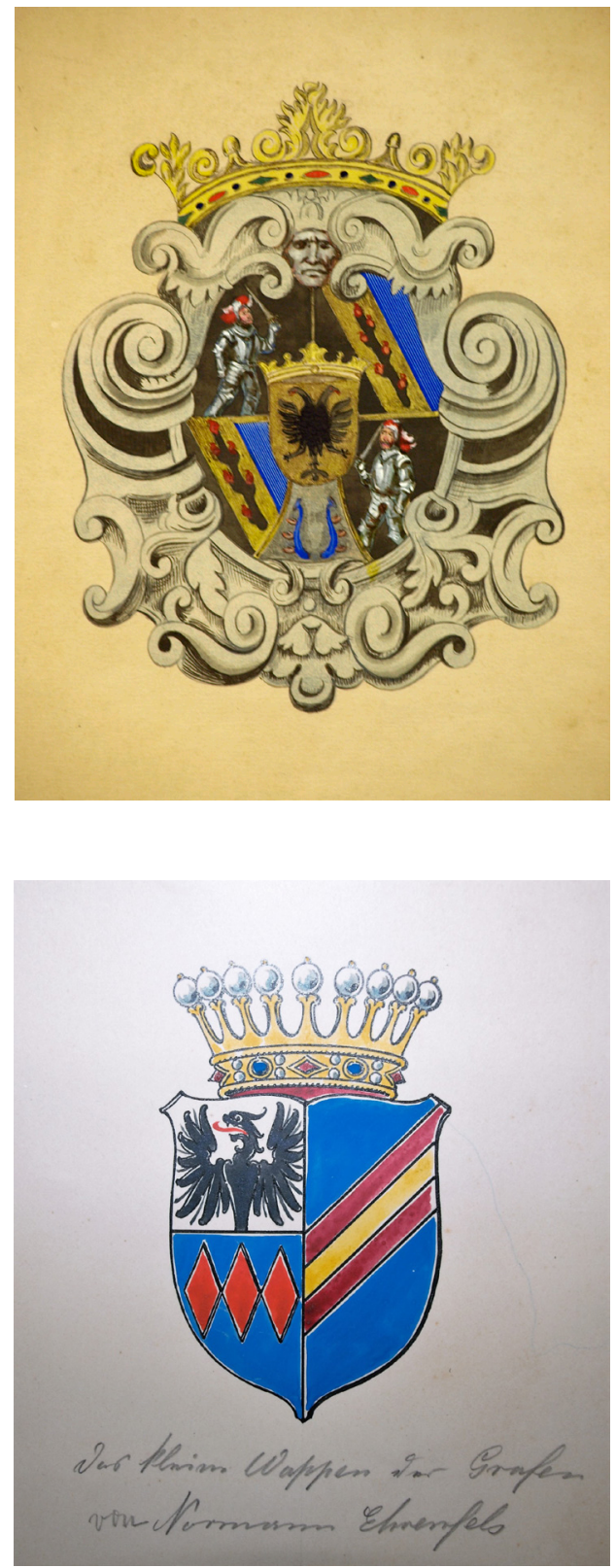

Slika 7

Ernst Krahl, grbovi obitelji Hilleprand von Prandau i Normann-Ehrenfels Muzej Valpovštine, foto: J. Najcer Sabljak 


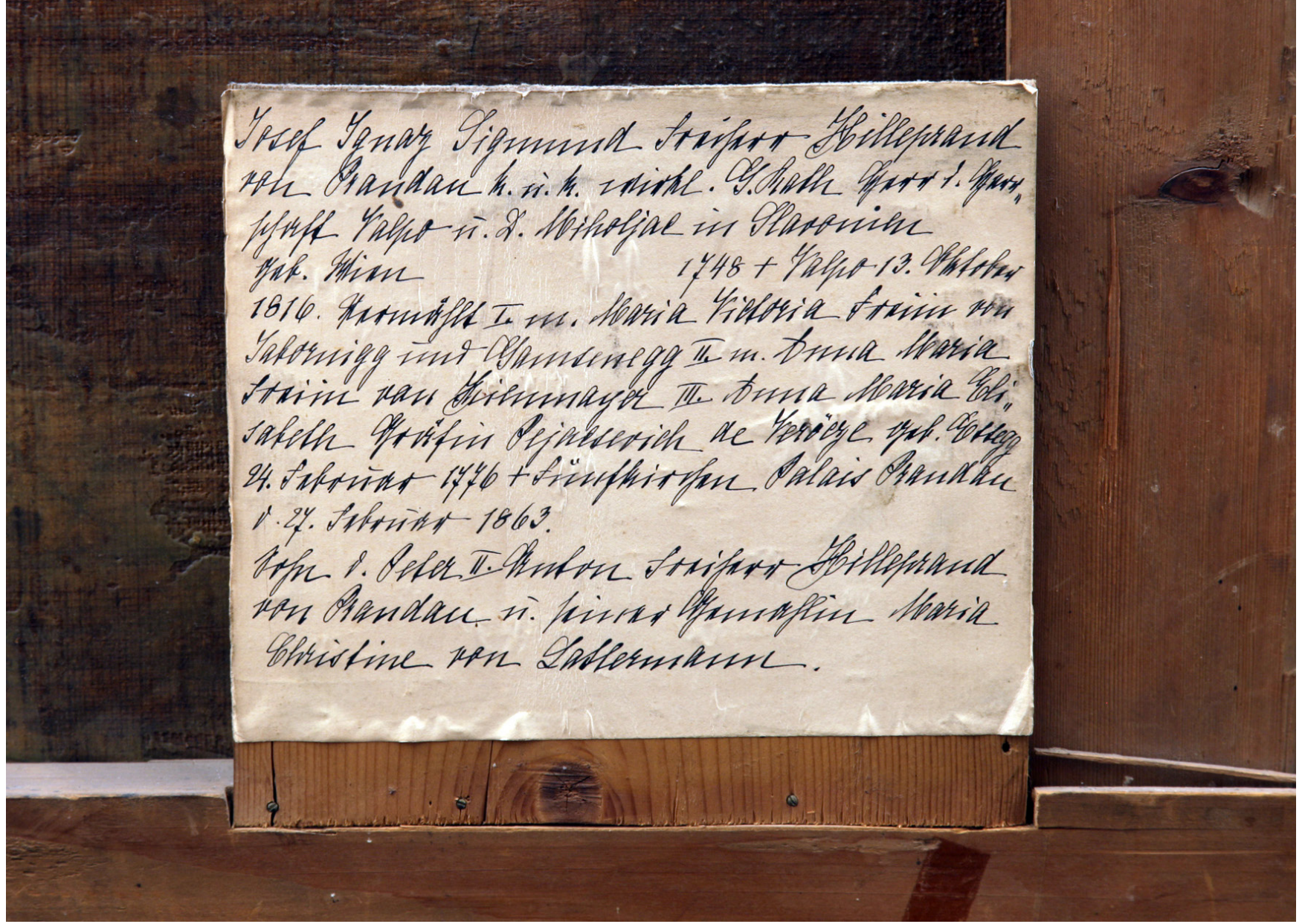

Uz već opisan angažman grofice Julije u izgradnji valpovačke zbirke njezina se briga za obiteljsku kolekciju uočava na još jednoj važnoj razini. Pregledom zbirke ustanovljeno je postojanje posebno dodanih pločica na poleđini slika s gusto ispisanim tekstom o sadržaju slike (biografski podaci portretirane osobe i podaci o slikaru; sl. 8). Arhivskim istraživanjem nepobitno je ustanovljeno da je rukopis Julijin, odnosno da je ona ispisala i postavila te zapise. Julija je na sve portrete (uobičajenih dimenzija i minijatura) dodavala na stražnjoj strani slike genealoške podatke na njemačkoj gotici u obliku listova nalijepljenih na podokvir ili okvir portreta, odnosno postavljenih na posebnoj drvenoj pločici koja je umetnuta između podokvira i platna. Ti podaci uvelike su olakšali istraživanje i proučavanje valpovačke zbirke u odnosu na ostale do sada proučavane plemićke zbirke istočne Hrvatske, a njezin je angažman u tom smislu jedinstven $u$ tom kontekstu. Julijina svijest o važnosti portreta kao dijela obiteljske, ali i šire društvene memorije, ostavljene u nasljedstvo novim generacijama, najuočljivija je upravo u tom njezinu postupku s umjetninama iz valpovačke zbirke. ${ }^{27}$
Slika 8

Tekst na njemačkoj gotici u rukopisu Julije grofice Normann-Ehrenfels o biografskim podacima portretirane osobe, pločica s poleđine portreta, foto: J. Najcer Sabljak

27 Paralelno je i u istraživanjima Marine Vinaj uočena njezina posebna briga za knjižnu baštinu valpovačkih vlastelina, odnosno za ukupno vlastelinstvo. MARINA VINAJ, Obiteljska knjižnica PrandauNormann: spomenička muzejska baština, u: Osječki zbornik, 30 (20II.), Osijek, 263-274; MARINA VINAJ, IVANA KNEŽEVIĆ KRIŽIĆ, Knjižnica PrandauNormann, u: Valpovački vlastelini Prandau-Normann, katalog izložbe, Osijek, 20I8., 7I-8I. 


\section{Bračni par Ehrenfels i donacije hrvatskim ustanovama}

Rudolf i Julija Normann bili su važne osobe hrvatskoga kulturnog i društvenog života, što je vidljivo i u donacijama hrvatskim ustanovama, kojima su darovali umjetnička djela, etnografski i numizmatički materijal. Bila je to svojevrsna potpora osnivanju i radu niza kulturnih institucija.

Tako je I907. Rudolf darovao novoutemeljenoj galeriji u Zagrebu spomen-plaketu Rudolfa Marschalla s likom biskupa Josipa Jurja Strossmayera, koja je izazvala aferu na hrvatskoj kulturnoj sceni. Plaketu je kod bečkog umjetnika Rudolfa Marschalla naručio Osječki građanski odbor u povodu biskupova 9o. rođendana, što je izazvalo nezadovoljstvo u krugu domaćih umjetnika. Kako je u međuvremenu biskup Strossmayer umro, Osječani su otkazali narudžbu plakete i sredstva preusmjerili za podizanje njegova spomenika u Osijeku. ${ }^{28}$ Možemo pretpostaviti da je nakon te afere grof Rudolf jedan odljev naručene plakete osobno otkupio od bečkog medaljara i darovao je galeriji koju je I905. godine improviziralo Hrvatsko društvo umjetnosti u prizemnoj prostoriji zagrebačkog Muzeja za umjetnost i obrt (sl. 9). ${ }^{29}$ Bili su to začeci današnje Moderne galerije u Zagrebu.
28 Autor je idejnog rješenja spomenika Rudolf Valdec Spomenik nije izveden, a njegova se skica čuva u Muzeju likovnih umjetnosti u Osijeku, Rudolf Valdec, J. J. Strossmayer, skica za spomenik, I9I5. g., bronca, 69 x 38 x 27,5 cm, inv. br. MLU-K-4I. ZDENKA MARKOVIĆ, Frangeš Mihanović, Biografija kao kulturno-historijska slika jedne epohe hrvatske likovne umjetnosti, Izdavački zavod Jugoslavenske akademije, Zagreb, I954., I6o-I62.

29 Plaketa je u fundusu Moderne galerije u Zagrebu, MG-348.
Slika 9

Rudolf Marschall, Brončana

plaketa biskupa Josipa Jurja Strossmayera I905.

Moderna galerija, Zagreb,

MG-348, foto: Goran Vranić
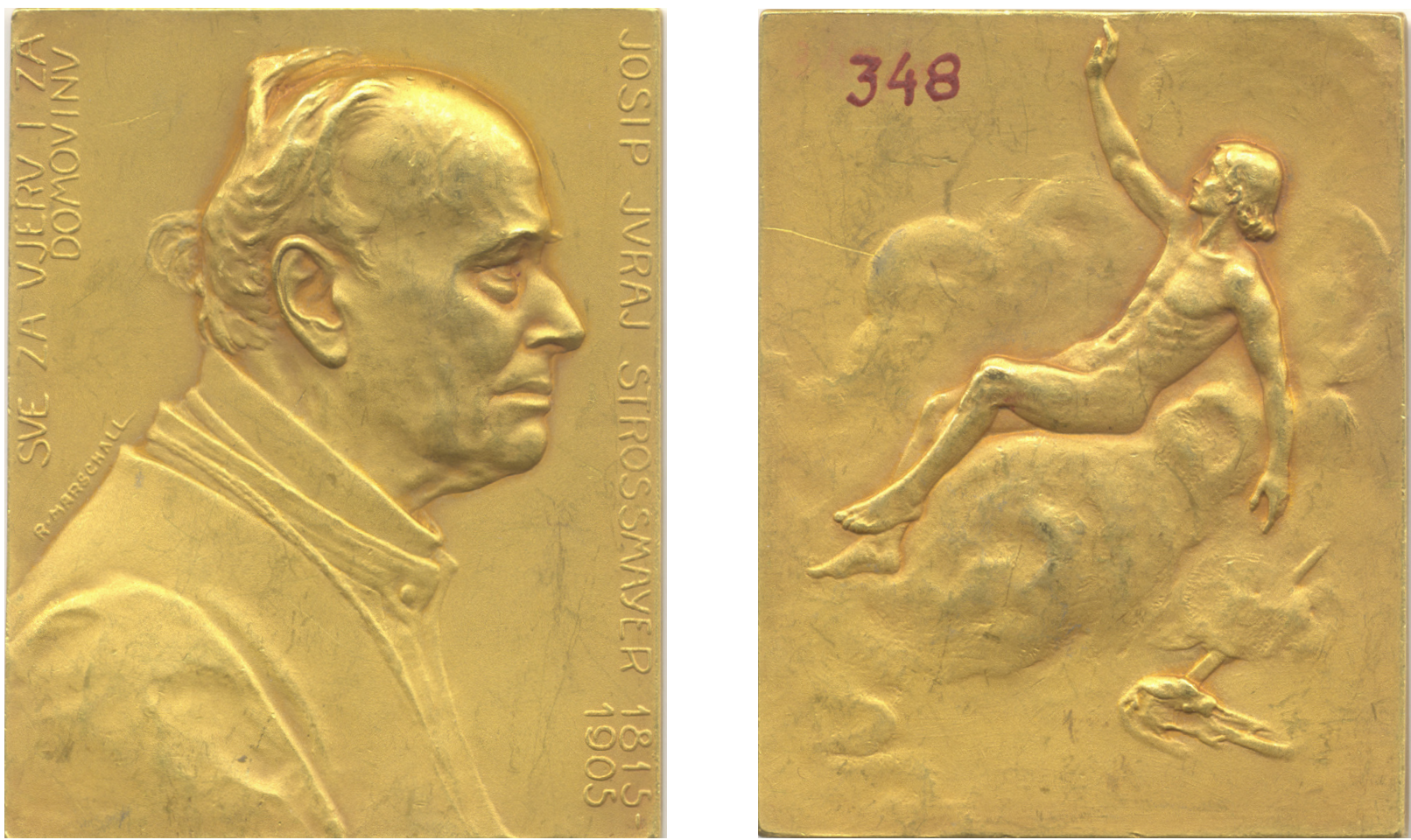
Rudolf Normann-Ehrenfels poklonio je I922. godine Galeriji starih majstora u Zagrebu (od I96I. godine Strossmayerova galerija) sliku Apostola Pavla bečkog slikara Karla Rahla, koja potječe iz ostavštine Pavla, grofa Pejačevića, odnosno podgoračke zbirke. ${ }^{30}$ Takve donacije smatrane su nacionalnom dužnošću uglednih građana i plemića, a svojedobno ih je poticao i utemeljitelj galerije te njezin najveći donator, biskup Josip Juraj Strossmayer. ${ }^{31}$ Rudolfova se donacija treba sagledati u kontekstu odnosa međusobnog uvažavanja i poštovanja koji je očigledno postojao između grofa Normanna-Ehrenfelškog i biskupa Strossmayera. O tom odnosu postoji još jedno materijalno svjedočanstvo. Godine Igoo. Strossmayer je slavio pedeset godina biskupske časti i tom je prigodom od Rudolfa dobio na dar reprezentativno izveden biskupski štap (pozlaćen, ukrašen dragim kamenjem), koji je u kombiniranoj tehnici izradio ugledni bečki draguljar Josef Carl Klinkosch. Na vrhu štapa graviran je na pločici prizor sv. Jurja koji ubija zmaja. Klinkoschev nacrt i fotografija biskupskog štapa čuvaju se $u$ Muzeju Slavonije, a štap se čuva u Nadbiskupskom dvoru u Đakovu, pa ga povremeno koristi i sadašnji đakovačko-osječki nadbiskup i metropolit Đuro Hranić. ${ }^{32}$

Brojne su predmete Rudolf i Julija darovali i osječkom muzeju (danas Muzeju Slavonije), poput lutaka u narodnim nošnjama (I9I4.) i vrijedne numizmatičke kolekcije (I940.), što je uvelike pridonijelo popunjavanju i formiranju muzejskih zbirki. ${ }^{33}$

\section{Valpovačka zbirka za vrijeme i nakon Drugog svjetskog rata}

Nakon smrti Rudolfa Normanna-Ehrenfelškog (I942.) te trajnog odlaska Rudolfa ml. i njegove obitelji na posjed Rothenthurn u Austriji (I944.), grofica Julija ostala je tijekom Drugoga svjetskog rata živjeti u valpovačkom dvorcu, a zbog ratnih zbivanja k njoj je došla i kći Marija Ana, ud. pl. Berks, sa suprugom iz Podgorača. Još tijekom rata grofica se brinula o sigurnosti obiteljske zbirke i dio vrijedne građe sklonila je na sigurno. Nakon I945. Julija je morala napustiti dvorac i nastaniti se kod bivšeg dvorskog upravitelja Josipa Pinterića, a živjela je od pomoći valpovačkih obitelji. ${ }^{34}$

U tim teškim vremenima inventar je valpovačkog dvorca bio devastiran, no najveći je dio umjetnina ipak bio sačuvan. Komisija za sakupljanje i čuvanje kulturnih spomenika i starina pri Ministarstvu prosvjete-Odjel za kulturu i umjetnost u Zagrebu, poznata pod kraticom KOMZA, nakon rata je preuzela iz dvorca dio valpovačke zbirke te niz djela podgoračke zbirke, koja se također čuvala u Valpovu. ${ }^{35}$ No dio valpovačke zbirke, mahom vrijedni obiteljski portreti, ostali su pod nadzorom grofice Julije, a bili su smješteni u župnom dvoru obližnje valpovačke crkve. Poznato je da su se u poslijeratnim godinama pregledom i popisivanjem sačuvane građe $u$ valpovačkom dvorcu bavili slavonski muzealci Danica Pinterović i Oto Švajcer.

Težak udarac Julija je doživjela smrću zeta Lothara pl. Berksa u valpovačkom zarobljeničkom logoru (25. rujna I945.) i kćeri Marije Ane od teške bolesti (26. lipnja r95I.). Nakon toga Julija
30 Slika je atribuirana i pripisana ostavštini podgoračke zbirke tijekom istraživanja likovne baštine obitelji Pejačević. JASMINKA NAJCER SABLJAK, SILVIJA LUČEVNJAK (bilj. 2), 47.

3I BORIVOJ POPOVČAK, Portreti Josipa Jurja Strossmayera: izložba u povodu I3o. obljetnice osnutka Strossmayerove galerije, Zagreb, 20I5., 5-6.

32 GRGUR MARKO IVANKOVIĆ, Josip Juraj Strossmayer u Osijeku (katalog izložbe, 20. svibnja 20I5.-4. veljače 20I6.), Muzej Slavonije, Osijek, 20I5., Io, 53-54.

33 GRGUR MARKO IVANKOVIĆ, ANTE GRUBIŠIĆ, I25 godina Muzeja Slavonije u Osijeku, Muzej Slavonije, Osijek, 2002., I4-I5.

34 MARINA VINAJ (bilj. I2), 329.

35 KOMZA u MSO pohranjuje sav preuzeti inventar valpovačkog dvorca: umjetnine, namještaj, predmete umjetničkog obrta i vrlo vrijednu i brojnu knjižnicu. KOMZA Osijek Io/46, (Arhiv MSO); KOMZA Zagreb 355/46 (Arhiv MK RH); JASMINKA NAJCER SABLJAK, Danica Pinterović i muzealizacija zbirki slavonskog plemstva, u: Zbornik radova sa Stručno-znanstvenog skupa Dr. Danica Pinterović-rad i djelovanje, Osječki zbornik, 34, Osijek (2018.), 99-ıо7. 
je uspjela dobiti vizu i otići I952. godine sinu Rudolfu u Austriju. No prije odlaska dio sačuvanih umjetnina (pedesetak slika) valpovačke zbirke pohranila je u osječkom muzeju. ${ }^{36}$ Julija je umrla u Rothenthurnu II. veljače I959., a sahranjena je u obiteljskoj grobnici na obližnjem groblju uz župnu crkvu u mjestu Molzbichl.

Tako se zahvaljujući osobnom angažmanu grofice Julije, osobe izrazito visoke svijesti o obiteljskoj baštini, sačuvao gotovo sav valpovački likovni materijal za buduće naraštaje. Za razliku od ostalog materijala slavonskih plemićkih zbirki, koje su bile opustošene, valpovačka zbirka ostala je gotovo cjelovita, a državnim vlastima predala ju je izravno posjednica. To je bila zadnja, no iznimno važna etapa u povijesti obiteljske zbirke, koju su potkraj I9. i početkom 20. stoljeća uspješno vodili i razvijali bračni par Rudolf i Julija Normann-Ehrenfels, zaslužno nazvani prijateljima umjetnosti.Zahvaljujući njihovim naporima zbirka je sustavno bogaćena i održavana s velikom pažnjom te je, uz osobni angažman Julije Normann-Ehrenfels, sačuvana od nestanka tijekom Drugoga svjetskog rata i u poraću. Građa iz te zbirke danas se nalazi u trima hrvatskim muzejskim institucijama: Muzeju likovnih umjetnosti i Muzeju Slavonije u Osijeku te Muzeju Valpovštine, gdje čini vrijedan dio fundusa i daje poticaj za dalje istraživanje, publiciranje i izlaganje.

Istraživanja za ovaj rad sufinancirala je Hrvatska zaklada za znanost projektom br. 4I53, Croatia and Central Europe: Art and Politics in the Late Modern Period (I780-I945).

\section{(ㄷ) (1)}

Valpovačka zbirka Rudolfa i Julije Normann-Ehrenfels / Jasminka Najcer Sabljak/CC BY / 4.0

DOI: https://doi.org/ıo.31664/z4khpu.o7
36 Popis predmeta Julije Normann-Ehrenfels koji su I9. lipnja I952. preneseni iz Valpova i pohranjeni u Muzeju Slavonije u Osijeku (502/52). Na popisu su umjetnine i predmeti dvorskog inventara (npr. satovi, fotografije, grbovi, samovar). Muzej Slavonije Osijek, knjiga ulaska 307, spis 502/52, 2I. srpnja I952. g. (Arhiv MSO). 